\title{
Study on the Marketing Operation Rules of Tourism Handicraft
}

\author{
Yan Zhang ${ }^{1, *}$ Hui Xie ${ }^{1}$
}

\author{
${ }^{1}$ Heihe University, Heihe, Heilongjiang, China \\ *Corresponding author. Email: 305468517@qq.com
}

\begin{abstract}
Tourism handicraft is a new derivative product with the development of tourism industry. As an important carrier of national culture, its essential connotation is the commercialization of national culture. Culture, technology and business environment constitute the inner relationship between tourism handicraft development and the commercialization of national culture. Excellent tourism handicraft comes from the perfect combination of art and culture, art and craft, art and material. Tourism handicrafts have rich regional characteristics and can reflect the culture of a certain region or country. To do a good job in the development of tourism arts and crafts projects, it is necessary to understand the tourists' consumption demand motivation firstly. Secondly, since tourists are people living in the society, when they buy tourism products, they will naturally be affected by different social factors, including social factors, cultural factors, personal factors and information factors. Therefore, it is necessary to follow the marketing operation rules of tourism handicraft, and constantly build a more high-quality and professional promotion and sales platform for tourism handicraft, and constantly innovate the marketing mode. Only in this way, can the development of domestic tourism handicraft industrialization be fundamentally promoted.
\end{abstract}

\section{Keywords: tourist handicraft, demand motive, influencing factors}

\section{INTRODUCTION}

Tourism handicraft is a new derivative product emerging with the development of tourism industry. It is an important carrier of national culture, and has an essential connotation of the commercialization of national culture. Culture, together with technology and business environment makes up the inner relationship between tourism handicraft development and the commercialization of national culture. As the staple and main body of tourist commodities, tourist handicrafts can not only bring certain economic benefits to tourist attractions, but also play an advertising role to enhance the popularity of tourist attractions. Tourism handicraft design and development are closely related to the development of tourism, and also reflect the progress of human civilization and the relationship between human and nature. Great tourism handicraft comes from the perfect combination of art and culture, art and craft, art and material. The grade and connotation of each scenic spot will expand outwards along with the development of high level tourist handicraft; the economic benefit of each handicraft workshop or enterprise is inseparable

*Project: "Construction Project of Wudalianchi Collaborative Innovation Center for Tourism Art Development", a scientific research operating fee project of Heilongjiang Education Department (Project No: 2018-KYYWF-1258). from the high artistic level of tourist handicraft sales maintenance; and the good memory of each tourist is inseparable from the aesthetic aftertaste of characteristic tourism crafts.

\section{THE DEMAND MOTIVE OF TOURISM HANDICRAFT}

\section{A. Analysis of tourism handicraft purchase demand}

During the journey, most tourists will buy tourism handicrafts, which have rich regional characteristics and can reflect the culture of a certain region or country. To do a good job in the development of tourism arts and crafts projects, the first step is to understand the purpose for which tourists buy tourism arts and crafts, namely, what kind of consumption demands do tourist crafts meet?

First of all, when tourists go to a country or region, they especially like the local culture or regional characteristics, since the characteristics of the place are never experienced by them. This curiosity and desire for new things stimulate tourists to buy local unique tourism crafts. The uniqueness of tourism handicraft refers to that it has special use value, something special in appearance and the use of special materials. Starting from these three points, the more unique it is, the more 
likely it is to stimulate tourists' consumption, that is, to meet their demands for exploring new and seeking for differences.

Secondly, tourist handicrafts represent local culture. Tourists buy tourist crafts in order to understand the local cultural connotation. The process of purchase is also a process of in-depth understanding, learning the regional culture, and show their own unique taste, to meet the needs of cultural taste tourists.

Again, for the traveler, at the end of a wonderful trip, what is it that fills this place with its regional characteristics, testifies that they have been to this place, and carries its love and desire for this place? The answer, of course, is tourism handicrafts. Tourist handicrafts meet the commemorative needs of tourists. If the travel handicraft has extremely exquisite workmanship and the material is unique and refined, it has a very large appreciation space. As for the tourist handicrafts which can be bought as collectibles, they also meet the collection needs of tourists.

Finally, tourists travel to a certain region or country and buy some tourism handicrafts with local characteristics to their friends and relatives. In this way, they can share the wonderful journey with their relatives and friends and deepen the emotional communication and exchange. Even if their relatives and friends have not experienced the journey in person, they can feel the local cultural characteristics. At this time, through the purchase of tourist handicrafts, travelers meet the needs of the social tourists.

\section{B. Analysis of motive of tourist handicraft buyers}

There are many motives for tourists to buy tourist crafts, such as novelty and interest, beautiful appearance, and they can be bought as commemoration, collection, or as presents for relatives and friends. Fundamentally divided, the motive of buying tourist crafts can be divided into two types: the motive of using for oneself and the motive of giving gifts to others.

First, tourists buy tourist crafts for their own use. It can be divided into three levels: novelty seeking, commemoration and collection. Tourism arts and crafts have regional characteristics. When tourists see the tourism arts and crafts they buy, they will think of the beautiful journey. Tourism arts and crafts have profound cultural deposits, thus can serve as to commemoration of the cultural journey for tourists; they can also be used for collection if the tourist buys a high-quality work of high artistic value.

Second, tourists buy tourist handicrafts as gifts for others. Since ancient times, Chinese people have such a habit that they will never forget to bring back some local objects to their friends and relatives wherever they go. In addition to communicating with each other, they can also share the details of their journey through these tourist handicrafts.

\section{FACTORS INFLUENCING THE PURCHASE OF TOURISM HANDICRAFTS}

\section{A. Social factors}

Tourists are people living in the society. When they buy tourism products, they will naturally be affected by different social factors. The following two social factors will be discussed on their impact of tourists' buying behaviors.

The buying behavior of tourists can be influenced by social class. Different social strata, purchasing power, consumption concept are different. And there are many similarities in the buying behaviors of tourists from the same social class. For example, when highincome groups buy tourist handicrafts, they will mostly choose some high-end consumption places and choose high-quality goods with high technology and high specifications. Price is not the main factor for them to consider. The low-income group will be more frugal when buying tourist crafts, and will choose some cheaper tourist crafts. Some groups with higher education have a strong ability to accept new things. When they buy tourist handicrafts, they pay more attention to the regional characteristics and cultural background of tourist handicrafts and pay more attention to spiritual enjoyment.

Secondly, tourists' buying behavior will be influenced by groups. The groups referred to here include tour guides, fellow team members and friends and relatives of tourists. Most tourists go to regions or countries that are relatively unfamiliar to them. When they buy tourist souvenirs, they are firstly influenced by the introduction of tour guides. Second, if one member of a team in the journey buys tourist artifacts, others will follow suit. Finally, the purchase information provided by friends and relatives will also have an impact on the purchase behavior of tourists.

\section{B. Cultural factors}

When tourists buy tourist handicrafts, they will be influenced by cultural factors to some extent. Cultural factors can be divided into two types. External cultural factors are tourists' cultural background, namely cultural differences. Different countries, regions and nations will shape different values and lifestyles. It is in order to experience different cultures that tourists travel to regions with different cultural backgrounds and are attracted by different regional cultures. The design and production of tourism handicrafts must pay attention to regional cultural characteristics, so as to attract tourists with different cultural backgrounds, stimulate their consumption and produce purchasing behavior. 
The influence of internal cultural factors is the influence of tourists' own cultural level on their buying behavior. When the group with high level of education buys tourist handicraft, it will take a fancy to the artistry of tourist handicraft on the basis of considering its practicality, pay attention to whether the craft of the article is consummate and analyze the value of tourism handicraft comprehensively. Therefore, tourists of this cultural level will particularly like to buy Chinese paintings, antiques and other higher grade tourism crafts. Comparatively speaking, tourists with a lower level of education have a simple purchasing behavior. They mainly focus on the cost performance of tourist handicrafts, and the lower the price, the better the handicrafts on the basis of achieving the required functions. The above is the influence of cultural factors on the buying behavior of tourists.

\section{Personal factors}

When tourists buy tourist crafts, they will not only be affected by social factors, cultural factors and economic factors, but also by personal factors. First of all, tourists of different ages are different in terms of financial resources, psychology and experience, and their buying behaviors will also be different. Young people with low income will choose some low-end shopping, and buy some inexpensive but unique and interesting crafts, which not only satisfy their curiosity, but also cost not much. Middle-aged and old tourists have accumulated certain amount of experience and financial resources, thus tend to choose tourism handicrafts with higher artistic value and cultural connotation, and the small and exquisite ones which are portable are especially favored. These are the effects of age on buying behavior.

Besides, men and women also buy travel crafts differently. While male do not pay attention to details and buy tourist crafts mainly as gifts for others, female pay much more attention to details, considering quality, craftsmanship, price, and practicality and enjoyment in particular.

Finally, the farther away tourists are from where they live, the more likely they are to be attracted to a tourist destination. In a place completely different from where they live, everything can be different, which will enhance tourists' desire to buy tourist crafts. In addition to the attraction factor of life difference, the farther the tourist destination is from the residence, the more tourists will consider the portability of tourist crafts. The above is the impact of residence on purchasing behavior.

\section{Information factors}

When tourists travel to an unfamiliar region or country, they will be influenced by a lot of tourism handicraft information when they buy tourism handicraft. Tourists do not know much about the artistry of tourist crafts, especially the collectibles of higher value. Information about tourism crafts can influence the buying behavior of tourists in the following ways.

One is the message from friends and family. This kind of information also has the biggest influence on the buying behavior of tourists. This is first because that friends and relatives are trustworthy; and they experienced it firsthand, so trust improved in the next place.

The second is all kinds of media publicity, such as network communication, sales staff to sell the introduction, tourism handicraft packaging and other information dissemination.

The third is the information obtained by tourists through research reports on tourism handicrafts release by the government and other authoritative departments. However, compared with the previous two kinds of information, this kind of information has a slightly weaker influence, because tourists' purchase behavior usually occurs in a relatively casual state, so it is difficult to plan in advance which tourist handicraft will be purchased in which place, let alone to check relevant authoritative reports in advance.

The fourth is the information spread by travel agencies and other relevant intermediary. The information disseminated in this way also has the least impact on the tourists. Since the travel society cooperates with some specific shopping sites, the guide can get the corresponding commission through introducing such products. Tourists will have some understanding of the "hidden rules" in this industry, so they start to guard against the introduction of the guide from the beginning, and fundamentally distrust it.

\section{CONCLUSION}

With the continuous development of the tertiary industry, the tourism handicraft market as an important contributor to the tertiary industry will usher in unprecedented development opportunities. Therefore, it is a must to follow the marketing operation rules of tourism handicraft. Constant efforts should be made to build a more high-quality and professional promotion and sales platform for tourism handicraft, and innovate the marketing mode. This is the only way to fundamentally promote the development of domestic tourism handicraft industrialization.

\section{References}

[1] Yang Ruihong, Liu Xiaoping, Tang Ping, et al. Design and Manufacture Basics of Tourism Art Crafts [M]. North Joint Publishing \& Media (Group) Co., LTD., 2009. (in Chinese) 
[2] Yang Yongmei, Wang Xiao. The Connotation Comparison and Scope Division of Applied Artwork and Design Patent on the Object of Protection - Also on the Idea of Applied Artwork Infringement lawsuit [J]. Application of Law, 2018, No.406 (13): 78-87. (in Chinese)

[3] Yi Zhen. Grass and Willow Weaving Crafts That Are Popular Abroad [J]. International Trade, 1983 (5): 29-29. (in Chinese)

[4] Yin Heng. Modeling Creativity and Design Methods of Tourism Handicraft Design [J]. Modern Manufacturing Technology and Equipment, 2018 (12): 93-94. (in Chinese)

[5] Yin Xiwen. Research on Design Ideas of Local Tourism Handicrafts [J]. Digital Fashion (New Vision Art), 2013 (05): 112-113. (in Chinese)

[6] Zhang Xiang, Wang Yanping, Yang Guihua. The Definition Situation of Ecological Civilization Tourism and Its Industrialization [J]. Ecological Economy, 2016,32 (6): 209213. (in Chinese) 